\title{
Visual Participatory Approach to Violent Behaviour amongst Zimbabwean Students: Forms and Prevalence
}

\author{
Ephias Gudyanga ${ }^{1}$, Nomsa Matamba ${ }^{1} \&$ Anna Gudyanga ${ }^{1}$ \\ ${ }^{1}$ Faculty of Education, Midlands State University, Gweru, Zimbabwe \\ Correspondence: Ephias Gudyanga, Faculty of Education, Midlands State University, P. Bag 9055, Gweru, \\ Zimbabwe. Tel: 263-7-7324-3468. E-mail: gudyangae@gmail.com
}

Received: December 10, 2013

Accepted: March 6, 2014 Online Published: April 29, 2014

doi:10.5539/ass.v10n10p30

URL: http://dx.doi.org/10.5539/ass.v10n10p30

\begin{abstract}
This study investigated the perceptions of students on forms and prevalence of violent behavior in Gweru urban district of Zimbabwe. Visual participatory methodology premised on both qualitative and quantitative paradigms was used. Drawings with focus group discussions were the main data collecting instruments. Participants were fifteen conveniently selected students attending a typical urban high school (females $=7$, age range 15-17, males $=8$, age range 14-18). Data on forms and prevalence of violence were collected from the students. The majority of the participants portrayed physical violence, vandalism and sexual harassment. It was recommended that schools must develop clear policies in an endeavor to reduce or eliminate violence. Schools Psychological Services must provide psychotherapy to individuals concerned. Visual participatory methodology, a new body of knowledge in Zimbabwe, is a vital tool for future researchers.
\end{abstract}

Keywords: violent, behavior, prevalence, visual, participatory, drawing, student

\section{Introduction and Background}

It has come to our attention and observation that violence appears to be on the increase in our institutions of learning. At times violence is associated with conduct disorders (Gudyanga, Nyamande, \& Wadesango, 2013). This is where children show a pattern of antisocial behaviour in everyday life at home or school when the behaviours are regarded as unmanageable by significant others. Fighting, lying, school problems, physical aggression are typical of children with conduct disorders (Gudyanga et al., 2013). Girls and boys are exposed to different forms of violence (Jefthas \& Artz, 2007). Girls tend to be victims of rape, harassment and sexual assault while boys appear to experience violence in the form of assaults and bullying. It has also been noted that more males than females are involved in violent behaviour (Wright \& Fitzpatrick, 2006; Kabuka, 2010). According to South African Council for Educators $\{$ SACE $\}$ (2011) the exact prevalence of violence in schools is unknown as many incidences go unreported. This has been attributed to the normalization of the problem in which the victim may feel that the case is not severe enough to be reported (Burton, 2008). Shoko (2012) reported a 92\% prevalence of Gweru boy students fighting, kicking or being kicked as one of the forms of violence, and a $20 \%$ of the cases amongst girls were being sexually harassed.

Victims of violence experience depression and low self-esteem, problems that can be carried into adulthood (Poipoi, Agak, \& Kabuka, 2010). They often feel insecure and rarely defend themselves (Kartal \& Bilgin, 2009). Public health specialists (Basch, 2011) have recognized that violence can result in injury, disability or death. Apart from physical injuries caused by violence, such behaviour affects the learning environment creating disruptions and an atmosphere of physical intimidation leading to anxiety and loss of focus on academic tasks (Wright \& Fitzpatrick, 2006).

Researchers conducted in developed countries provided information regarding the nature and extent of violent behaviour among students in schools. In United Kingdom (UK) bullying behaviour is a pervasive problem (Aluede, 2011). For example, Whitney and Smith's study of 6758 students in twenty four schools in areas of the City of Sheffield revealed that 27 percent of the elementary and middle schools' sample reported being bullied during the term (Aluede, 2011). In Canada, rates of violence is high among adolescents with 10 percent to 11 percent of students reporting that they are frequently victimized by peers and 8 to 11 percent admitted to have bullied others (Hyme, Rocke, Honderson, \& Banero, 2005) as cited in (Aluede, 2011). 
Basch (2011) revealed that 34 percent of public schools' principals reported daily or weekly bullying as a problem. Physical fighting was commonly reported by blacks and Hispanics 44.7 percent and 40 percent respectively than whites 31.7 percent. Schwaston, Funti, Jones, \& Ruchkin (2004) as cited in (Wegner, Santiago, Nishimura, \& Hishimura, 2010) revealed that adolescents in Hawaii tend to model the behaviour manifested by others.

Rudatsikira, Siziya, Kazombe, \& Muula (2007) reported that 50690 adolescents in Namibia had engaged in a physical fight. In recent years, Jamaica has suffered from an epidemic of violence that has left many individuals dead and many more wounded or physically disabled (Bailey, 2012). In 2006 the Jamaican Youth Risk and Resiliency behaviour survey looked at youth involvement in violence. They found out that $20 \%$ of male adolescents were reported to be carrying guns and 17 percent were involved in gang activities (Bailey, 2012).

The Centre for Justice and Crime Prevention in 2007 carried out a national study in South Africa and found out that $15.3 \%$ of primary and secondary school learners had experienced some form of violence at school. It was established that vandalism that included breaking of window panes, blocking of toilets, damaging plants and trees and scratching of teachers' cars were common among students (Marcus \& Meier, 2010).

It is against this background that we decided to carry out this study on identification of forms and prevalence of violent behaviour amongst students at Nharira secondary school, in Gweru urban district, in the Midlands province of Zimbabwe.

The research questions that guided this article were:

1) Which are the forms of violent behaviour among students at Nharira secondary school?

2) What is the prevalence of such violent behaviour among the same students?

\section{Method}

The study was conducted in a school located in Gweru high density suburb. Gweru district is located in the Midlands province of Zimbabwe. The school was purposively selected because it was deemed to provide information concerning violent behaviour. We targeted Ordinary Level students. It is observed that violent behaviour is high among Ordinary Level students hence the need to establish forms and prevalence of violent behaviour among those students at Nharira secondary school (a fictitious name given for ethical reasons).

This study is grounded in an ecosystemic approach (De Lange, 2008) in that all layers or levels of the ecosystem, i.e., the individual, the family, the school, possess valuable understandings of the issues at hand. This is put together in order to look at the issues pertaining to violent behaviour by students in schools. The ecosystem approach looks on the broader social context in which social problems like violence are resolved. Visual participatory methodology is considered suitable for the current research because it involves an interpretative naturalistic approach to the world (Mitchell, 2011). This approach, the first ever to be used in Zimbabwe, is motivated by an in depth inquiry to study a phenomenon in its natural setting as well as to interpret the phenomenon in terms of meaning and understanding constructed by people (Denzim, 2003). Visual participatory methodology tends to focus on a smaller population but probing deeper into a given problem (Richards, 2011; Mitchell, 2011). We adopted this methodological approach to understand students' perceptions on the forms and prevalence of violent behaviour among students. Visual participatory methodology allows open ended views to be formed therefore giving a more comprehensive understanding of participants and their experiences. We believed that by using visual participatory methodology to gather data, new insights and ideas would emerge from the study and this would bring about the greater understanding of the prevalence of violent behaviour that the researchers sought.

There are a range of visual methods which can be used, for instance photography, painting, drawing and videography which produce data in material visual form (Richards, 2011). Visual participatory methodology gives participants a sense of ownership over the research process and this makes them more likely to invest time and energy required to make the project a success (Richards, 2011; Deacon, 2000). Thus for the sake of the current research, we used drawings to solicit for information about the forms, and prevalence of violent behaviour among students.

Drawings can provide data in a fun and creative manner and participants can be actively engaged in the data collection process by asking them to draw (Deacon, 2000). This method actually brings out information that may remain hidden during verbal interviews (Lorenz \& Kolb, 2009). Visual methods promote a more divert understanding of people, their life experiences and their perceptions than is possible with data controlled solely by the researcher (Lorenz \& Kolb, 2009). 
Due to their engaging nature, participatory drawings emerge to be a highly efficient research strategy that is suitable when working with young people. The more involved the participants are in the different aspects of the research, the increased likelihood of long term personal benefits for those taking part (Richards, 2011). Drawing can be used in order to understand how people see the world (Guillemin, 2004). Interpretations of the meanings of the drawn images were done so that depiction of concepts, emotions and information in an expressive, empowering and personally relevant manner was done.

The target population for this research includes violent Ordinary Level students at Nharira secondary school in Gweru urban. The selection of Ordinary Level students was based on the view that violent behaviour was observed to be high at upper forms. Secondly the students were the main source of information as they were the ones exhibiting violent behaviour.

We identified the school as a place where violent behaviour was very rampant among students. The school was purposively selected as it was deemed to be rich with the information. Since the current research focused on the actual students involved in violent behaviour, purposive sampling was used to select the actual participants. Participants were selected on the basis of their availability and willingness to respond (Gravetter \& Forzano, 2006). Hence only those who were observed to be violent and willing to participate in the research were selected and used.

A sample of fifteen (15) students was selected for both drawing method and focus group discussion, (eight boys and seven girls, age range 14 to 18 years). The number of participants was motivated by the need to have a detailed analysis of the phenomenon under study. For example, drawings had a minimum of five sessions over a period of two weeks.

The focus group discussions were conducted using the same students who were selected for drawings under participatory visual methodology. Focus group discussions were meant to enrich information obtained through drawings as students were able to explain some of the underlying factors driving violent behaviour among students in their school. We compiled notes during the interview session. In order to avoid dominance by few individuals during the interview session, we provided a platform for all individuals to participate without feeling intimidated or inferior by giving each participant the room to make contributions, pertaining to his/her drawing and issues relating to prevalence of violence in the school.

We explained the study method that is, drawings to the participants as well as the aim and purposes of the study. We explained to the participants that when answering the question asked they should do so in the form of drawings. The participants answered two research questions of which the first one had to solicit for the form(s) of violence which the participants often observe in their school. The participants had to draw these forms of violence. The second one was answered through focus group discussions. The focus group members answered the question on the frequency of the identified forms of violent behaviour.

The participants and the researchers had five sessions. The participants answered first research question through construction of drawings. In the first two sessions we encouraged the participants to feel free to express themselves in interpreting the meanings of their drawings. In the third and fourth session, serious in depth discussions were done with respondents about each and every drawing so that intense meanings were deduced to address the research questions. The last and fifth session was a group discussion on the prevalence of violence.

It is during the fifth session that the participants discussed as a group about their drawings and any other issues observed relevant in as far as prevalence of violence was concerned. During the discussion session, the participants took the lead while we listened and gave necessary guidance. Participants in the study gave their consent in writing before commencement of the study after the purpose of the study and what would be expected of them had been explained. Since their selection was purposive, they were assured that they were free to withdraw at any stage without any negative consequences. Pseudonyms were assigned to participants to maintain and guarantee anonymity and confidentiality.

\section{Results}

\subsection{Forms of Violence Exhibited by the Students}

In our attempt to answer the first research question, the participants through their drawings indicated different forms of violent behaviour that are exhibited by students in the school. The main forms of violent behaviour that were revealed by the participants included fighting, shouting/scolding, vandalism and sexual harassment.

Seven participants through their drawings reported that physical fighting is the most prevalent form of violent behaviour that is exhibited among the students. During the focus group discussions, eleven participants admitted to have been involved in physical fighting during the term. Student A had this to say in local language. 


\section{'Ini ndakamborwa mushure mekunge ndatukwa zvinogwadza neumwe mwana wechikoro'.}

This student was saying that he was involved in a fist fight with another student after hateful words were used against him. Figure 1 depicts a situation whereby students were witnessing fighting between two female students. Of the bystanders who were present, only one person is saying;

\section{'Vabatei imi'}

On translation, this means that only one student wanted to intervene so that they could stop the fight and the rest of other students present were actually cheering them so that they could continue to fight hence they say;

\section{'Anobata tinorova. Siya varwe, rova!'}

The other three (3) students standing together in the drawing were cheering and were saying that the female students who were fighting should be left alone to fight and anyone who tried to intervene would be beaten up. The other students were actually enjoying watching fellow colleagues fighting. Other by stander is even threatening to also beat up anyone who is seen attempting to intervene with the aim to stop the fight.

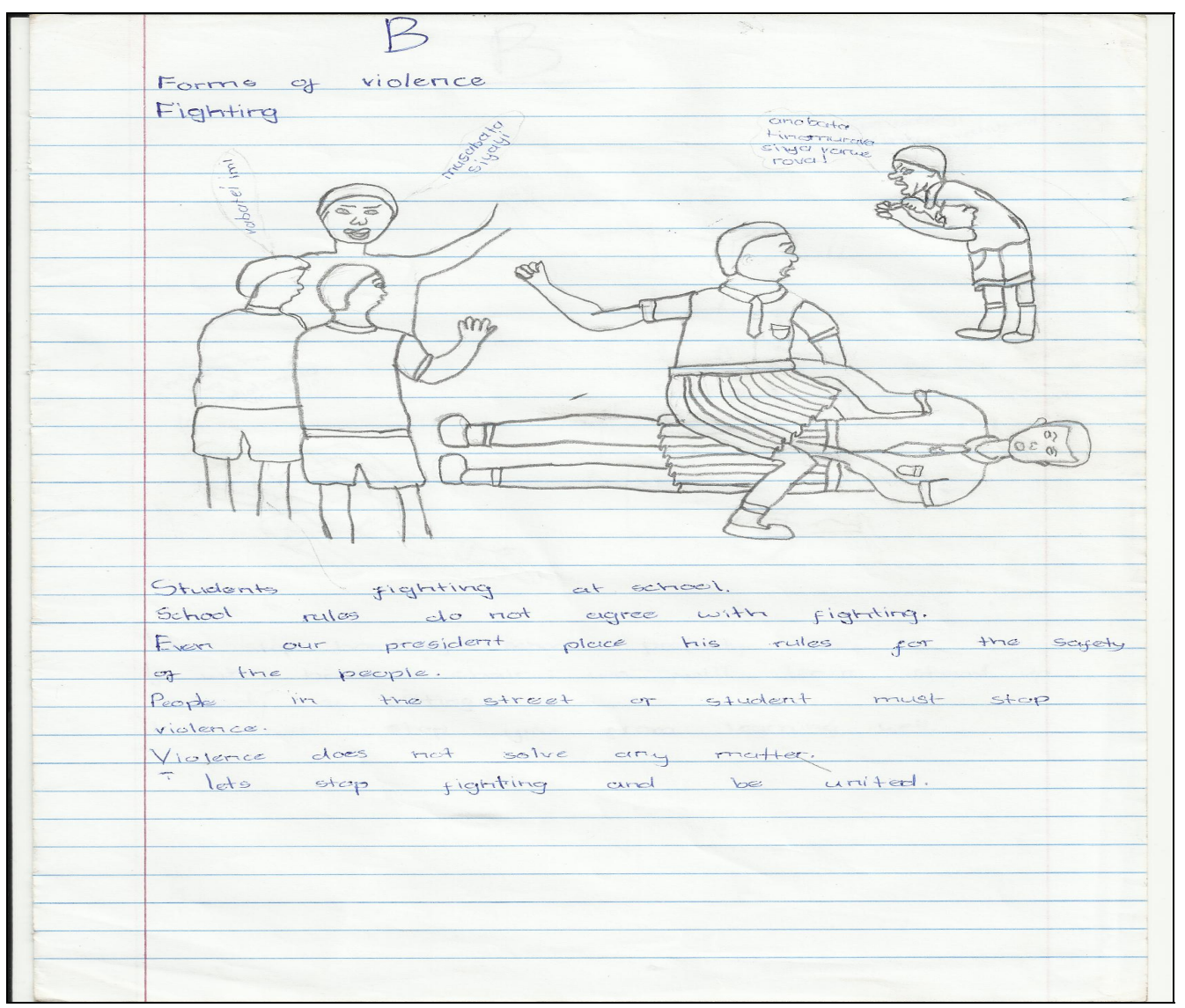

Figure 1. Female students fighting in the presence of others

Seven participants produced drawings depicting fighting. Some of the participants' drawings show students using hateful words and vulgar language towards each other. Student C and I pointed out that sometimes students scold each other over issues like the use of someone's pen or ruler by force or without the consent of the owner. In figure 2 a male and a female student are scolding each other. The drawing shows that the male student was scolding the girl because of the vulgar language that was used by the female student towards him and was very angry. During focus group discussions, it was noted that scolding was common among students. Four female participants indicated that they usually find themselves exhibiting this form of violent behaviour. All students concur that insults and scolding of one another is the order of the day in the school. 


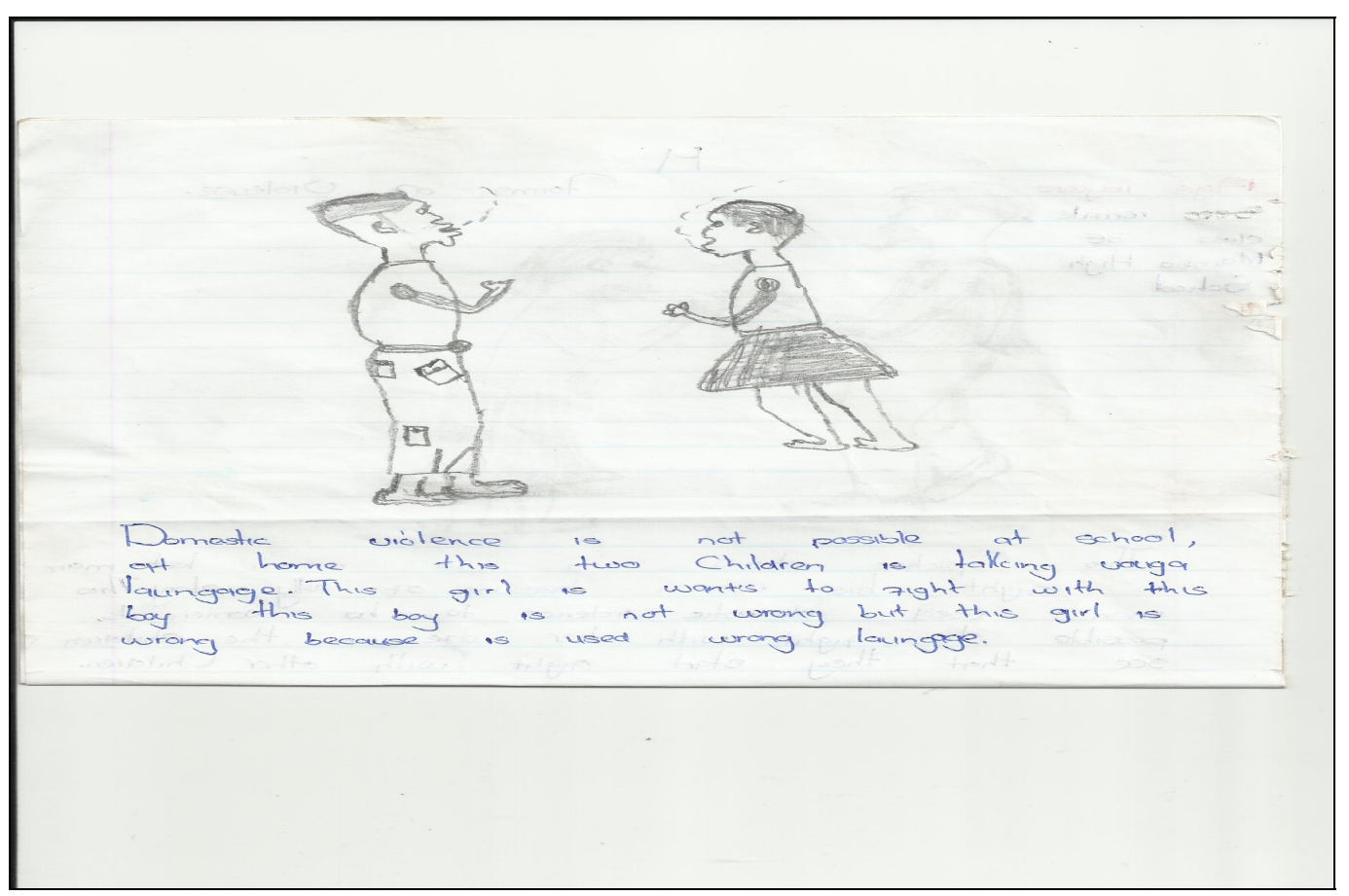

Figure 2. A female and male student scolding each other

Vandalism of school property like chairs, window panes and door locks were mentioned by four students. Students $\mathrm{E}$ and $\mathrm{K}$ had drawings of students breaking the window panes using stones (figure 3). Student $\mathrm{M}$ had a drawing of a student breaking a door lock while student B had a drawing of a student jumping on top of the desk attempting to break it (drawings not shown). This behaviour normally results in loss of school property.

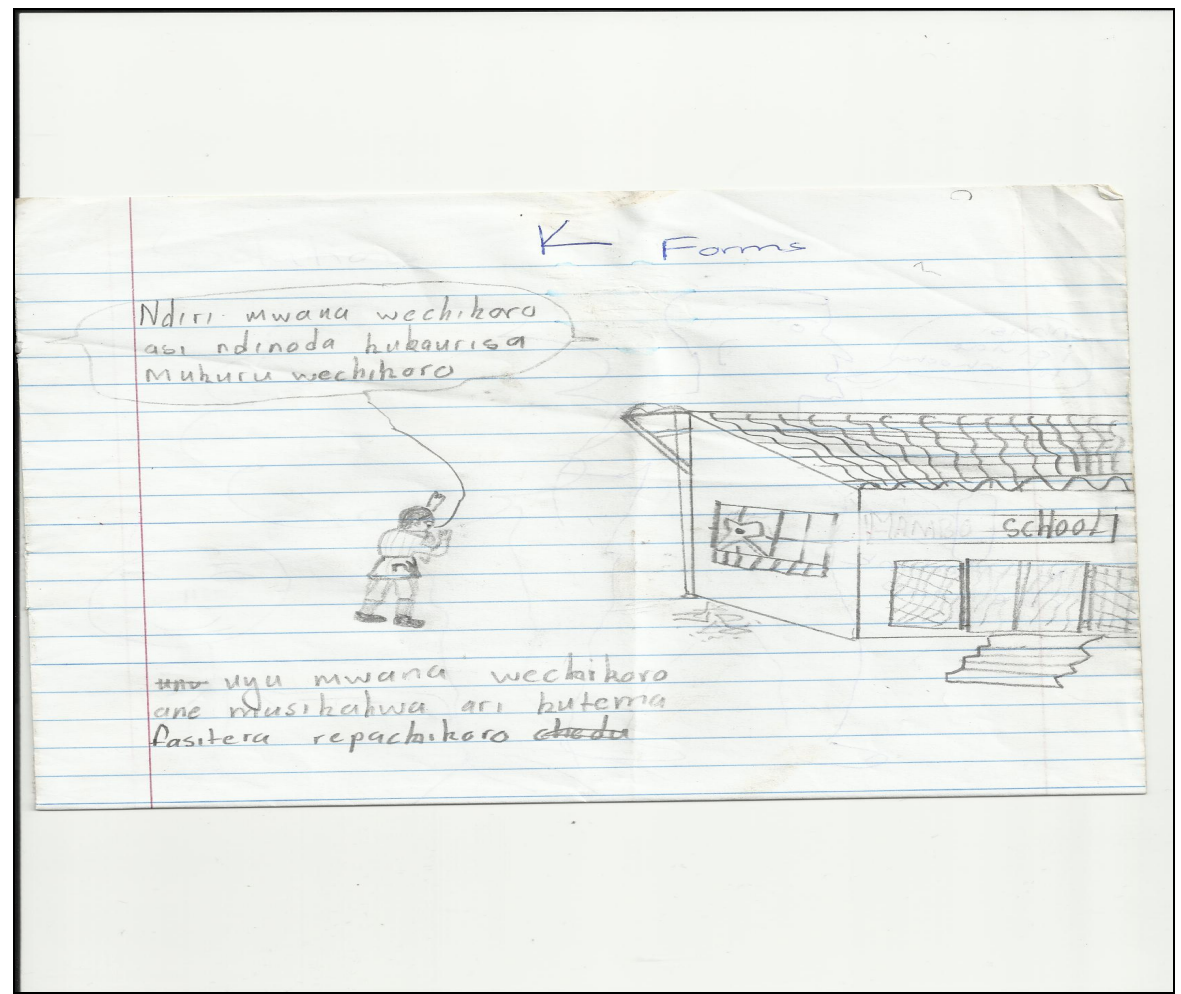

Figure 3. A Male student throwing a stone and breaking window panes 
Focus group discussions revealed that sexual harassment is one of the serious issues in the school. In the majority of the cases, girls are more prone to violence through sexual harassment. All the girls $(\mathrm{N}=7)$, concurred that boys harass them through breast fondling and patting at the buttocks. Such unbecoming behaviour culminates in fist fights or scolding of one another in the school, said one of the girls.

\subsection{Prevalence of Violence}

Each of the participants was asked to write secretly on a piece of paper indicating how frequently he/she exhibits violent behaviour in one form or another. It was observed that eight students engage in violent behaviour in the school at least once per week followed by three participants who admitted to be involved in violent behaviour at least once per two weeks. Two participants indicated that they were involved at least once per month while two participants exhibited violent behaviour once per term.

\section{Discussion}

\subsection{Forms of Violence Exhibited by the Students}

Findings indicate that students engage in different forms of violent behaviour and this includes mainly fighting, scolding, vandalism and sexual harassment. The current study revealed that fighting was the most common form of violent behaviour that was exhibited by the students. Poipoi et al., (2010); SACE, (2011) argue that some of the general categories of school violence include bullying, fighting and assaulting inside or outside the school premises. Other forms included bringing drugs and other harmful components to the school (Bardick \& Bernes, 2008), sexual harassment, vandalism, robbing or stealing, bringing weapons and firearms in the school premises (Aluede, 2011). Such form of behaviours exhibited by school children is indicative of conduct disorders (Gudyanga et al., 2013) of which psychotherapy is called for. Schools psychological services department is responsible for that.

The findings above confirm observations of Valois, Paxton, Zullig, \& Huebner, (2006) that physical fighting was above 50 percent prevalent for males and black females. Rudatsikira, Siziya, Kazombe, \& Muula, (2007) assert that the majority of the adolescents in Namibia engage in physical fight. Figure 1 depicts a situation whereby students witness two female students fighting and are actually cheering them up. This reflect the social and cultural norms of the society in which the students come from, which makes fighting a more acceptable and normal behaviour. This indicates that other students condone violence as they see no evil in this act. This perception must be changed to restore normalcy in the school. During further debate in focus group discussion, we observed that some students had moments of reflection on their violent behaviours. One would almost visualize disgust, anguish and perhaps turmoil on their faces. The students seem not to like violence but they find themselves already in it, said one boy. The reason why one may choose to fight instead of resolving misunderstandings amicably may best be explained by Freud's Instinct theory which states that humans are born with aggressive instincts (Fieldman, 2009). These instincts create a drive to commit aggressive acts that must be satisfied. The Freudian catharsis pressure is associated with the aggressive drive which is reduced by any aggressive act like fighting with others at school. Hence there is need for teachers to support the students in learning constructive conflict resolution strategies. Extra curricula activities like playing ball games, and being involved in athletics, are highly recommended such that aggressive students may exude their energy in a constructive and acceptable form.

Bullying and fighting according to Gasa (2005) is an act of seeking power or attention through the psychological, emotional or physical abuse of another person. This type of violence is found in most schools and bullying is common among students who have a mindset of annoying or dominating others. Scolding one another was said to be common among female students hence they had drawings which depict scolding as a form of violence. Some of the drawings depicted students scolding each other using vulgar language. During the focus group discussions all the female participants $(\mathrm{N}=7)$ admitted to have shouted angrily or used vulgar language towards other students. Basch (2010) revealed that hateful words were exhibited by students in the study that he carried out. Shoko (2012) in her study in rural day secondary schools of Gweru revealed that students harass each other verbally using nasty comments. The findings suggest that these hateful words against each other actually lead to physical fighting. There is need for the learners to be taught what to do in anger instigating situations.

School violence according to Barwick (2009) includes any verbal, physical, psychological or visual manifestation intended to directly or indirectly threaten, the rights of others within the school setting. Basch (2011) revealed that verbal aggression and physical fighting was commonly reported by Blacks and Hispanics than whites.

Vandalism is another form of violence that was mentioned by four participants in the study. Drawings show 
students breaking down window panes, door locks and desks. Figure 3 shows a male student throwing a stone at the window panes. Manguwo, Whitney, \& Chareka (2011) reported that vandalism to school property was a common form of violence. Vandalism was mainly an expression of anger or frustration among students, either originating from home or at school. This may be explained by the frustration-aggression theory which suggested that frustration produces anger leading to the readiness to act violently (Berkorowitz, 2001; cited in Fieldmcan, 2009). It is possible that those students who are frustrated by harsh parental discipline at home or at school by too much work might have aggressive energy created within them which activates violent behaviour which would be manifested through vandalism. Thus vandalism to school property is a form of catharsis. Teachers must therefore teach students how to control angry feelings that can initiate aggressive behaviour.

Vandalism as pointed out by Estevez, Herrero, Martinez, \& Musitu (2006) includes damage and destruction of properties of others intentionally just in order to seek some attention. Manguwo, et al. (2011) conducted a research in schools in Harare (Zimbabwe) and found out that vandalism to school property was a cause for concern.

Morais and Meier (2010) in their research with foundation phase teachers found out that vandalism was a serious problem. According to the respondents, breaking of windows, blocking of toilets using tissues, scratching of teacher's cars and damaging plants were some of the forms of vandalism that were manifested by their students. The foundation phase teachers also revealed that fighting in the classroom and on playground manifests as pushing, slapping, kicking and aggressive fight.

Sexual harassment towards girls by school boys was one form of violence reported by all girls $(\mathrm{N}=7)$. The violence (harassment) included breast fondling, patting of the buttocks, slapping of girls by boys and physical assault. Although sexual relationships between adults and young children are perceived as abusive (Shumba et al., 2008), relationships involving adolescents are interpreted with more ambiguity. For example, adolescents themselves are often uncertain if patting of girls' buttocks by boys constitutes harassment (Corbett, Gentry, \& Pearson, 1993). Indeed, some boys might consider buttock patting as some form of play and perhaps not constituting violence on the opposite sex. However, the girl child is experiencing some sexual violence in the school, of which solutions to curb such behaviour is needed.

A study conducted in South Africa by the Centre of Justice and Crime Prevention in 2007 revealed that violence experienced by males and females are different (SACE, 2011). Girls tend to be victims of sexual harassment and sexual assault while boys tend to be physically assaulted and bullied (SACE, 2011). A study conducted in Kenya's Western Province revealed rioting, bullying, sexual violence and fighting as common forms of school violence (Poipoi et al., 2010). From the same research male respondents identified bullying as the least form of violent behaviour while bullying was the most common form of violence among female students followed by fighting and lastly sexual violence.

In Zimbabwe, a study conducted by Shoko (2012) in Gweru rural schools established that educators concurred that students harassed each other both verbally and physically. The same study revealed that making nasty comments, hitting and kicking were most common forms of violence among students.

\subsection{Prevalence of Violence}

The majority of the participants engage in violent behaviour at least once per week. Most of the students admitted to have been involved in violent acts at least once per week (Kartal \& Bilgin, 2009). Three participants reported that they were involved in violent behaviour at least once per fortnight while two participants were involved in violent behaviour at least once per month. These findings clearly show that violence among students is a problem as the majority cannot exceed seven days without exhibiting violent behaviour. One may conclude that the frequency was high and some psychotherapy by schools psychologists is justifiable. Policies must be put in place in order to curb or minimize occurrence of violent behaviour. School management boards must put in place policies to minimize violence in schools or putting a stop to it. School pupils must enjoy being in school. The community leaders must be involved in the curbing of violence. In Zimbabwe school pupils spend about nine (9) months in the school environment and another three (3) months on school vacation in every year. The nine months must be enjoyed by the student if the school environment is violence free. Students' interaction must be hilarious and violence free. Schools must put in place violence reporting mechanisms where the complainant must be fully protected both at school and outside the school premises. Currently, it would appear that many incidents go unreported. Some violence may seem to be like a normal daily activity; hence such violent behaviour may go unreported. The violent behaviour seems "normal". The victim may feel that the case is not severe enough to warrant any reporting.

Data collected by the Crime and Safety Survey Program in USA between July 2009 and June 2010 revealed that 
there were 33 secondary schools associated with violent deaths in elementary and secondary schools. In 2010 females had lower rates of violent victimization. During the 2009 and 2010 school year $28 \%$ of students aged 12-18 reported being bullied at school. In 2009 a higher percentage of females $20 \%$ than males $13 \%$ reported being the subject of rumors. A lower percentage of females $8 \%$ than males $10 \%$ reported being pushed, tripped or spit on (National Centre for Education and Statistics, 2012). If schooling is to be enjoyed by students, violence must be stamped out. All stakeholders must be involved.

The limitation of this study is that a small urban sample was used. It is argued and recommended that a larger sample including rural students be used to verify findings. The study was carried out within one school, surrounded by a community with uniform cultural setting, which may have a bearing on the findings. It is suggested that future research should focus on groups of participants from several schools in different societal and cultural settings.

\section{Conclusions}

The current study was undertaken out of concern about the forms and prevalence of violence in schools. Violent behaviour is a common problem in the school where the study was conducted as evidenced by forms and high prevalence. Schools psychological services are to give appropriate psychotherapy. Communities are encouraged to fully participate.

Schools are encouraged to put into place policies and mechanisms that curb violence. The implementation of such policies must be monitored by the school management boards together with the board of parents (School Development Associations-SDA's). Since SDA's is a board of parents with children attending that particular school, this board is deemed to be effective in the implementation of such policies since the parents are an interested party. Environments free from violence will be conducive to proper learning and will be amenable to improved academic and social life of students. Serenity and tranquility must be the expected tone and ethos of every school.

The school must have a clear policy on how to effectively deal with violent behaviour among students. The school must engage parents and guardians through meetings and workshops in an endeavor to adopt and implement collaborative initiatives towards reduction or elimination of violent incidences among students. There must be effective dual communication between school authorities and the parents in order to enhance the spirit of co-operation and teamwork to deal with the indiscipline among students. The school must indoctrinate a culture of tolerance and remorse among students. Schools also need to purchase enough furniture for the students. Communities must instill correct and good values and norms in the hearts and minds of children as they grow up. The values like ability to work amicably with others, avoidance of hurting one's neighbor, loving and caring for one another are some of the basic values expected to be practiced by every society.

The curriculum for pre-service training of teachers should include more information regarding conflict management so that teachers will be equipped with relevant knowledge regarding conflict management in schools. The study was limited to one school, hence more studies can be done which includes more schools in order to generalize the findings on a larger scale.

The violent students who break the law must be dealt with both at local level (the school) and state level (the police). If such procedures are adopted, they will act as deterrents and schools will be a hub of learning excellence and best grounds for breeding future leaders of our nations. It is highly encouraging to note that this is the first research ever in Zimbabwe to use visual participatory methodology hence this new body of knowledge will assist other future researchers.

\section{Acknowledgements}

This paper was partly a result of the contributions made by the students of Nharira high school. We acknowledge their input.

\section{References}

Aluede, O. (2011). Managing bullying problems in Nigerian secondary schools: Some Counseling intervention for implementation. The African symposium, Online Journal of the African Educational Research Network, 11(1), 138-144.

Amado, J., \& Freire, I. (2003). Violent prevention in schools using the internet: A European Perspectives. Retrieved from http://www.bullying-in-school.Info/en/contents/facts-figuring/sbv-prevention.html

Babour, S. (2011). What are the causes of violent behaviour in children? Retrieved from http://www.livestrong.com/article/251743-what-are-the-causes-of-violent-behavior-in-children/ 
Bailey, A. (2012). The Jamaican adolescents' perspectives on violence and its effects. West Indian Medical Journal, 60(2), 65-81.

Banks, M. (2007). Using visual data in qualitative research. London: Sage publications.

Bardick, A., \& Bernes, K. (2008). A framework for assessing violent behaviour in Elementary school age children. Children and Scholars, 30(2), 41-59. http://dx.doi.org/10.1093/cs/30.2.83

Barwick, M. (2009). School violence: What you should know and what you can do. Retrieved From http://www.cbc.ca/news/health/story/2009/04/20/f-barwick-school-violence.html

Basch, C. (2011). Aggression and violence and the achievement gap among urban minority Youth. Journal of School Health, 81(10), 619-625. http://dx.doi.org/10.1111/j.1746-1561.2011.00636.x

Benavente, J. (2008). What makes children violent? Retrieved from http://www.ext.colostate.edu/pubs/columncc/cc031202.html

Bergold, J., \& Thomas, S. (2012). Participatory research methods: A methodology approach in motion. Qualitative Social Research, 13(1), 30-42.

Bester, S., \& Plessis, A. (2010). Exploring a secondary school educators experiences of school violence: A case study. South African Journal of Education, 30, 203-229.

Blakeslee, K. (2003). Unsafe schools: A literature review of school related gender based violence in developing countries. Retrieved from http://pdf.usaid.gov/pdf_docs/PNACU253.pdf

Bosworth, K., Ford, L., \& Hernandaz, D. (2011). School climate factors contributing to student and faculty perception of safety in selected Arizona schools. Journal of School health, 81(4), 1204-1216. http://dx.doi.org/10.1111/j.1746-1561.2010.00579.x

Burton, P. (2007). Dealing with school violence in South Africa. Centre of Justice and Crime, 4, 1-8.

Celbis, O., Karaoglu, L., Egri, M., \& Ozolemir, B. (2012). Violence among high school students in Malatya: A prevalence study. Turkey Journal of Medical Science, 42(2), 343-350.

Chamaz, K. (2006). Constructing grounded theory: A practical guide through qualitative analysis. London: Sage publications.

Cohen, J., Mccabe, E., Mitchell, N., \& Pickeral, T. (2009). School climate: Research, policy, practice and teacher education. American Psychological Association, School Psychology Quarterly, 27(3), 154-169.

Corbett, K., Gentry, C. S., \& Pearson, W. Jr. (1993). Sexual harassment in high school. Youth and Society, 25, 93-103. http://dx.doi.org/10.1177/0044118X93025001006

De Lange, N. (2008). Visual participatory approaches to HIV \& AIDS research as intervention in rural community setting. Journal of Psychology in Africa, 18(1), 181-186.

Deacon, S. (2000). Creativity within qualitative research on families: New ideas for old methods. The qualitative Report, 3(4), 1-6.

Debarbieux, E. (2003). School violence and globalization. Journal of Education Central Administration, 41(1), 582-602. http://dx.doi.org/10.1108/09578230310504607

Difonzo, R., Gall, K., \& Quante, D. (2008). Education post Columbia: An overview of violence in schools in the 21st century. New York: Sage publications.

Drolet, M., Paquin, M., \& Soutyrine, M. (2007). Strengths based approach and coping strategies used by parents whose young children exhibited violent behaviour: Collaborative between school and parents. Child Adolescent Social Work Journal, 24, 437-453. http://dx.doi.org/10.1007/s10560-007-0094-9

Estevez, C., Herrero, J., Martinez, B., \& Musitu, G. (2006). Aggressive and non-aggressive rejected students. Psychology in the Schools, 43, 387-400. http://dx.doi.org/10.1002/pits.20152

Estevez, E., Jimenez, T., \& Gonzalo, M. (2008). Violence in and victimization at school in adolescence. Madrid: Nova science publishers.

Fieldman, R. (2009). Understanding Psychology. New York: McGraw Hill.

Frey, A., Ruchkin, V., Martin, A., \& Schwab-Stone, M. (2009). Adolescents in transition, school and family characteristics in the development of violent behaviour. Psychiatry and Human Development, 40(1), 1-13. http://dx.doi.org/10.1007/s10578-008-0105-x 
Gasa, V. G. (2005). Learner 's aggressive behaviour in secondary schools: A psycho-social Perspective, (Doctoral thesis, University of South Africa). Retrieved from http://uir.unisa.ac.za/bitstream/handle/10500/2432/thesis.pdf? sequence=1

Gottfredson, G., Gottfredson, D., Payne, A., \& Gottfredson, N. (2005). School climate predictors of school disorders: Results from a national study of delinquency prevention in schools. Journal of Research in Crime and Delinquency, 42(4), 412-444. http://dx.doi.org/10.1177/0022427804271931

Gravetter, F., \& Forzano, L. (2006). Research methods for behavioral sciences. New York: Wadsworth.

Gudyanga, E., Nyamande, W., \& Wadesango, N. (2013). Assisting students with conduct disorders in Gweru urban primary schools: Issues and challenges. Journal of Psychology, 4(2), 47-57.

Guillemn, M. (2004). Understanding illness: Using drawing as research methodology. New York: Routledge.

Harris, H. (2013). Contributory factors that precipitate school violence. Retrieved from $\mathrm{http}: / / \mathrm{www}$. ehow.com/info_7988607_contributing-factors-precipitate-school-violence.html

Husain, M. (2004). An investigation into factors that may contribute to school violence in male high school in Kuwait. (Unpublished doctoral thesis). Virginia Polytechnic Institute and State University, USA.

Kartal, H., \& Bilgin, A. (2009). Bullying and school climate from the aspects of the students and teachers. Eurasian Journal of Educational Research, 9(36), 209-226.

Knoblaunch, H., Baer, A., Laurier, E., Petschke, S., \& Schnettier, B. (2008). Visual analysis. New developments in the interpretive analysis of video and photography. Forum Qualitative Social Research, 9(3), 7-14.

Lahey, B. (2008). Psychology. New York: Sage publications.

Lorenzo, L., \& Kolb, B. (2009). Involving the public through visual participatory research method. Health Expectations, 12(3), 262-274. http://dx.doi.org/10.1111/j.1369-7625.2009.00560.x

Manguwo, A., Whitney, S., \& Chareka, C. (2011). The crisis of student misbehavior in Zimbabwe public schools: Teacher's perception on impact of macro socio economic challenges. The African symposium, Online Journal of the African Educational Research Network, 11(2), 155-161.

Marais, P., \& Meier, C. (2010). Disruptive behaviour in the foundation phase of schooling. South African Journal of Education, 30(1), 41-57.

Mertens, D. (2005). Research and evaluation in education and psychology. Integrating diversity with qualitative, quantitative and mixed method. London: Sage publications.

Mitchell, C. (2011). Doing visual research. London: Sage publications.

Paterson, C. (2012). Classroom behaviour of children living in contexts of adversity (Unpublished master's thesis). Faculty of Education, Stellenbosch University, South Africa.

Poipoi, M., Agak, J., \& Kabuka, E. (2010). Teachers and students` perceptions of psychological factors contributing to violent behaviour among public secondary school students in western province, Kenya. African Journal of History and Culture, 2(6), 83-101.

Poipoi, M., Agak, J., \& Kabuka, E. (2011). Perceived home factors contributing to violent behaviour among public secondary school students in Western province. Journal of Emerging Trends in Educational Research and Policy Studies, 2(1), 30-40.

Rayment, T. (2006). Managing boy`s behaviour. New York: MPG Books limited.

Reddington, F. (2007). Youth violence and delinquency, monsters and myths. New York: Praeger publishers.

Resnick, M., Ireland, M., \& Borowsky, I. (2004). Youth violence perpetration: What protect? What predicts? Findings from the national longitudinal study of adolescents. Journal of Adolescent Health, 35, 424. http://dx.doi.org/10.1016/j.jadohealth.2004.01.011

Rudatsikira, C., Siziya, S., Kazombe, L., \& Muula, A. (2008). Variables associated with physical fighting among United States high school students. Clinical Practical Epidemical Health, 4, 1-8.

Shoko, N. (2012). Educator`s perception of peer harassment among rural day secondary school pupils in Gweru, Zimbabwe. Asian Social Science, 8(13), 80-88. http://dx.doi.org/10.5539/ass.v8n13p80

Shumba, A., Gwirayi, P., Shumba, J., Maphosa, C., Chireshe, R., Gudyanga, E., \& Makura, A. H. (2008). Pupil's perceptions of sexual abuse by teachers in Zimbabwe. Journal of Psychology in Africa, 18(2), 279-282. 
Smallhood, D. (2003). Defusing children's violent behaviour. New Jersey: EBSCO.

Smallhood, D., \& Kern, E. (2006). Defusing violent behaviour in schools. New Jersey: Philadelphia College of Osteopathic Medicine.

South African Council for Educators. (2011). School based violence report: An overview of school based violence in South Africa. Retrieved from http://www.sace.org.za/upload/files/School\%20Based\%20 Violence\%20Report-2011.pdf

Thomas, S., \& Smith, H. (2004). School connectedness, anger behaviours and relationship of violent and nonviolent American youths. Psychiatric Care, 40(4), 29-37.

Valois, R., Paxton, R., Zullig, K., \& Huebner, S. (2006). Life`s satisfaction and violent behaviour among middle school students. Journal of Child and Family Studies, 15(6), 695-705. http://dx.doi.org/10.1007/s10826-006-9043-z

Wegner, E., Santiago, O., Nishimura, S., \& Hishimura, E. (2010). Educational reference and attitude towards school as risk protective factors for violence: A study of the Asian Pacific Islander youth violence. Prevention Centre Psychology in the Schools, 47(8), 789-802. http://dx.doi.org/10.1002/pits.20504

Wright, D., \& Fitzpatrick, K. (2006). Social capital and adolescence violent behaviour: Correlates of fighting and weapon use among secondary school students. The University of North Carolina Press Social Forces, 84(3), $1436-1448$.

\section{Copyrights}

Copyright for this article is retained by the author(s), with first publication rights granted to the journal.

This is an open-access article distributed under the terms and conditions of the Creative Commons Attribution license (http://creativecommons.org/licenses/by/3.0/). 